\title{
PEMANFAATAN BONGGOL PISANG (Musa paradisiaca L.) DALAM RANSUM TERHADAP PERFORMA AYAM BROILER
}

\author{
Kidejus Kupai, Jet S. Mandey*, Youdhie H. S. Kowel, dan Mursye N. Regar \\ Fakultas Peternakan Universitas Sam Ratulangi Manado, 95115
}

\begin{abstract}
ABSTRAK
Penelitian tentang pemanfaatan bonggol pisang sepatu (Musa paradisiaca L.) dalam ransum broiler bertujuan untuk mengetahui sejauh mana pengaruhnya terhadap performa, yaitu konsumsi ransum, pertambahan bobot badan, dan konversi ransum ayam broiler. Ayam yang digunakan yaitu ayam broiler unsexed umur 1 hari sebanyak 100 ekor. Penelitian ini menggunakan Rancangan Acak Lengkap (RAL) yang terdiri dari 4 perlakuan dan 5 ulangan. Susunan perlakuan sebagai berikut: $\mathrm{R} 0=55 \%$ jagung $+0 \%$ tepung bonggol pisang (TBP), R1 $=50 \%$ jagung $+5 \%$ TBP, R2 $=45 \%$ jagung $+10 \% \mathrm{TBP}, \mathrm{R} 3=40 \%$ jagung+ $15 \%$ TBP. Hasil penelitian menunjukan bahwa perlakuan memberikan pengaruh yang berbeda nyata terhadap konsumsiransum, bobot badan, dan konversi ransum. Berdasarkan hasil penelitian disimpulkan bahwa bonggol pisang dapat digunakan sampai $10 \%$ dalam ransum ayam broiler.
\end{abstract}

Kata kunci: Bonggol pisang, Broiler, Performa.

\section{ABSTRACT}

UTILIZATION OF BANANA CORM (Musa paradisiaca L.) IN DIET ON BROILER

CHICKENS

PERFORMANCE. The research on the utilization of banana (Musa paradisiaca L.) corm in broiler diet aimed to determi

\footnotetext{
*Korespondensi (Corresponding author):
} Email: jetsm_fapet@yahoo.co.id ne its effect on the performance of broilers, namely the feed intake, weight gain, and feed conversion ratio. The birds used were 100 unsexed days old chicks. This study used a Completely Randomized Design (CRD) consisting of 4 treatments and 5 replications. The composition of the treatment as follows: $\mathrm{R} 0=55 \%$ corn $+0 \%$ banana corm meal $(\mathrm{BCM}), \mathrm{R} 1=50 \%$ corn $+5 \% \mathrm{BCM}, \mathrm{R} 2$ $=45 \%$ corn $+10 \%$ BCM, R3 $=40 \%$ corn $+15 \% \mathrm{BCM}$. The result showed that the treatment had a significantly different effect on feedintake, body weight, and feed conversion ratio. Based on the results of the study, it was concluded that banana corm can be used up to $10 \%$ in broiler chicken diet.

Keywords: Banana corm, Broiler, Performance.

\section{PENDAHULUAN}

Peningkatan jumlah penduduk Indonesia dari tahun ke tahun berdampak pada peningkatan konsumsi produk peternakan (daging) yang secara tidak langsung memberikan peluang usaha dalam memajukan industri peternakan di indonesia. Ternak unggas memberikan kontribusi yang besar terhadap pemenuhan gizi khususnya protein hewani. Ayam broiler adalah salah satu jenis ternak ayam yang mudah 
dipelihara, pertumbuhannya cepat, dan murah biaya pemeliharaannya. Hasil akhir dari broiler adalah daging yang merupakan sumber protein asal hewani yang banyak dikonsumsi oleh masyarakat dengan harga relatif terjangkau.

Faktor penting yang sangat mempengaruhi keberhasilan usaha peternakan ayam broiler adalah pakan, karena pertumbuhan yang optimal dipengaruhi oleh kualitas dan kuantitas pakan yang dikonsumsi. Penyediaan bahan baku pakan hingga kini belum tertanggulangi dengan baik, dalam arti kompetisi pangan dan pakan masih terus berlanjut, sehingga menimbulkan dilema bagi nutrisionis dan konsumen. Di samping itu, penyediaan bahan pakan sering mengalami kendala yaitu mahalnya harga pakan akibat sebagian bahan pakan tersebut seperti tepung ikan, jagung dan kedele masih didatangkan dari luar daerah, bahkan dari luar negeri, sehingga pada akhirnya akan meningkatkan biaya produksi. Mandey et al. (2017) menyatakan bahwa perhatian sekarang sedang difokuskan pada bahan pakan alternatif murah tapi sesuai dengan kebutuhan. Pemanfaatanbahan pakan non konvensional atau lokal yang lebih murah dan tersedia telah banyak dipraktekkan untuk mengurangi masalah ini.
Usaha untuk mengatasi ketersediaan jagung yang semakin terbatas yaitu dengan mencari bahan pakan alternatif yang kualitasnya hampir sama dengan jagung. Salah satu bahan pakan yang tersedia dan belum sepenuhnya dimanfaatkan dalam ransum, khususnya ransum unggas, yaitu bonggol pisang (Musa paradisiaca L.) yang dapat dijadikan suatu alternatif untuk penyediaan pakan sumber energi.Keputusan memilih bahan pakan alternatif ini pentingagarenergi yang tersediadalam menyusun ransum ayam pedaging terjamin, sehingga produksiyang diharapkan dapat tercapai (Mandey et al., 2017)

Bonggol pisang merupakan limbah yang sangat potensial sebagai bahan pakan karena jumlahnya yang melimpah dilihat dari jumlah produksi pisang yang cukup melimpah, dan juga merupakan bahan pakan sumber energi, dimana energi bruto bonggol pisang adalah 4,288 Kcal (Sumarsih et al., 2009). Produksi pisang di Indonesia pada tahun 2017 jumlahnya mencapai 7.162.678 ton, pada tahun 2018 meningkat menjadi 7.264.379 ton dan tahun 2019 mencapai 7.280.658 (BPS, 2020).

Keunggulan dari bonggol pisang sepatu (Musaparadisiaca L.) sebagai bahan pakan adalah kandungan patinya 
yang tinggi. Pati tanaman pisang selain ditemukan pada buah, juga terdapat padabonggol. Bonggol pisang tidak dimanfaatkan lagi setelah pemanenan buah, karena itubonggol pisang yang merupakan salah satu bagian dari tanaman pisang berupa umbi batang dapat dimanfaatkan (Suyanti dan Supriyadi, 2008).

Hasil Analisis di Laboratorium Ilmu MakananTernak Fakultas Peternakan UGM menunjukkan komposisi kimia bonggol pisang sebagai berikut: protein $2,38 \%$, serat kasar 4,47\%, lemak $0,87 \%$, kalsium $0,06 \%$, fosfor 0,15\%, dan energi bruto $3202 \mathrm{Kcal} / \mathrm{kg}$. Saragih (2013) melaporkan bahwa tepung bonggol pisang dalam $100 \mathrm{~g}$ memiliki kandungan zat-zat makanan, yaitu : karbohidrat 79,16, serat kasar 29,62, protein kasar 3,58, dan abu 1,82.

Kelemahan bonggol pisang adalah mengandung zat anti nutrisi tanin yang dapat memberikan pengaruh kurang menguntungkan terhadap pemanfaatan zat-zat makanan.Hasilpenelitian menunjukkanekstrak etanolbonggolpisang mengandung senyawa flavonoid, glikosida, terpenoid dan tanin (Venkatesh et al.,2013). Priosoeryanto et al. (2007) melaporkan bahwa tanin, flavonoid dan saponin dari ekstrak pelepah pisang berfungsi sebagai antibakteri dan dapat membantu pertumbuhan sel baru pada luka.

Bonggol pisangmerupakan bahan buangan yang cukup banyak jumlahnya. Berdasarkan data jumlah produksi pisang, maka limbah bonggol pisang yang dihasilkan melimpah.Penelitian Ulfa dan Djunaidi (2019) tentang penggunaan campuran tepung bonggol pisang dan Indigofera sp. sebagai pengganti bekatul menunjukkan adanya peningkatan konsumsi pakan, pertambahan berat badan, indeks performans dan income over feed cost serta dapat menurunkan konversi pakan. Perlakuan terbaik adalah penggunaan campuran tepung bonggol pisang dan Indigofera sp. Sebagai pengganti bekatul sebesar $10 \%$. Selanjutnya hasil penelitian Puspitasari et al. (2019) bahwa pemanfaatan tepung bonggol pisang sampai 10\% menggantikan pakan control pada ayam pedaging mampu mempertahankan berat karkas serta meningkatkan persentase karkas dan menurunkan lemak abdominal ayam pedaging dengan pemberian pada level 10\%. Taran, et al. (2015) melaporkan bahwa kualitas daging broiler yang diberikan perlakuan kombinasi tepung bonggol pisang hingga $24 \%$ dan tepung daun kelor hingga $10 \%$ sebagai pengganti jagung menghasilkan keempukan daging ayam broiler 
dengan sifat fisik yang baik dan secara organoleptik dapat diterima oleh konsumen.

Berdasarkan latar belakang pemikiran di atas, maka telah dilakukan penelitian mengenai pemanfaatan bonggol pisang sepatu dalam ransum dengan tujuan untuk melihat sejauh mana pengaruhnya terhadap performa ayam broiler.

\section{MATERI DAN METODE PENELITIAN}

\section{Waktu Dan Lokasi Penelitian}

Penelitian ini telah dilaksanakan di kandang percobaanunggas Fakultas Peternakan Universitas Sam Ratulangi Manado, selama 5 minggu.

\section{Materi Penelitian}

Penelitian ini menggunakan 100 ekor ayam broiler unsexed strain Cobb (PT. Charoen Pokphand) umur 1 hari, dan dipelihara sampai umur 5 minggu, dengan rataan berat badan awal 21,8522,11 gram.

\section{Kandang dan Peralatan}

Kandang yang digunakan adalah jenis kandang battery berukuran $20 \times 30$ x $30 \mathrm{~cm}^{3}$ terdiri dari 20 unit kandang dansetiap unit ditempati 5 ekor ayam. Setiap kandang dilengkapi tempat makan dan minum. Perlengkapan lain yang dingunakan yaitu lampu pijar 60 watt, timbangan digital O'haus, wadah untuk mencampur ransum perlakuan, koran bekas, ember, kuas dan sendok untuk menggambil ransum sisa, sapu lantai, dan alat tulis menulis.

Tabel 1. Komposisi Zat Makanan dan Energi Metabolis Bahan Pakan Penyusun Ransum.

\begin{tabular}{lcccccc}
\hline \multicolumn{1}{c}{ Bahan makanan } & $\begin{array}{c}\text { Protein } \\
(\%)\end{array}$ & $\begin{array}{c}\text { Serat } \\
\text { kasar }(\%)\end{array}$ & $\begin{array}{c}\text { Lemak } \\
(\%)\end{array}$ & $\begin{array}{c}\text { Ca } \\
(\%)\end{array}$ & $\begin{array}{c}\mathrm{P} \\
(\%)\end{array}$ & $\begin{array}{c}\text { Energi } \\
\text { metabolis } \\
(\mathrm{Kcal} / \mathrm{kg})\end{array}$ \\
\hline Bonggol pisang** & 2,38 & 4,47 & 0,87 & 0,06 & 0,15 & 3203,00 \\
Jagung* & 8,10 & 3,45 & 7,71 & 0,17 & 0,70 & 2865,75 \\
Tepung kedele** & 42,02 & 6,40 & 13,22 & 0,21 & 0,65 & 3603,00 \\
Bungkil kelapa* & 20,55 & 15,88 & 15,07 & 0,21 & 0,49 & 3279,75 \\
Dedak* & 8,36 & 16,53 & 6,58 & 0,18 & 0,84 & 3724,50 \\
Tepung ikan** & 63,6 & 0,5 & 9,3 & 5,81 & 3,23 & 2564,25 \\
Top mix* & - & - & - & 5,38 & 1,44 & - \\
Keterangan:*Hasil Analisis Laboratorium Ruminansia \& Kimia Makanan FakultasPeternakan Unpad \\
Bandung (2017). \\
Hasil Analisis Laboratorium Ilmu Makanan \\
2017). Ternak Fakultas PeternakanUGM, Yogyakarta (Mandey,
\end{tabular}


Tabel 2. Susunan Ransum Perlakuan, Komposisi Zat-Zat Makanan dan Energi Metabolis

\begin{tabular}{|c|c|c|c|c|}
\hline Bahan ransum & R0 & R1 & $\mathrm{R} 2$ & R3 \\
\hline Bonggol pisang (\%) & 0 & 5 & 10 & 15 \\
\hline Jagung (\%) & 55 & 50 & 45 & 40 \\
\hline Tepung kedelai (\%) & 10 & 10 & 10 & 10 \\
\hline Bungkil kelapa (\%) & 10 & 10 & 10 & 10 \\
\hline Dedak (\%) & 9,5 & 9,5 & 9,5 & 9,5 \\
\hline Tepung ikan (\%) & 15 & 15 & 15 & 15 \\
\hline Top mix (\%) & 0,5 & 0,5 & 0,5 & 0,5 \\
\hline Total & 100 & 100 & 100 & 100 \\
\hline \multicolumn{5}{|l|}{ Zat-Zat Makanan* } \\
\hline Protein $\%$ & 20,88 & 20,59 & 20,31 & 20,03 \\
\hline Serat kasar \% & 5,69 & 4,16 & 5,79 & 5,84 \\
\hline Lemak \% & 10,19 & 9,85 & 9,51 & 9,17 \\
\hline $\mathrm{Ca} \%$ & 0,33 & 0,29 & 0,29 & 0,28 \\
\hline $\mathrm{P} \%$ & 0,68 & 0,65 & 0,63 & 0,60 \\
\hline $\begin{array}{l}\text { Energi metabolis } \\
(\mathrm{Kcal} / \mathrm{kg})\end{array}$ & 2977,01 & 2993,87 & 2977,00 & 3027,60 \\
\hline
\end{tabular}

Keterangan : *Dihitung berdasarkan Tabel 1.

\section{Ransum Percobaan}

Bahan-bahan makanan yang digunakan sebagai penyusun ransum yaitu tepung bonggol pisang sepatu, tepung jagung kuning, tepung kedelai, bungkil kelapa, dedak, tepung ikan dan top mix. Tabel 1, menampilkan komposisi zat makanan dan energi metabolis bahan makanan penyusun ransum, sedangkan Tabel 2. menyajikan susunan ransum perlakuan serta komposisi zat-zat makanan dan energi metabolis

\section{Metode Penelitian}

Penelitian ini menggunakan metode eksperimen dengan Rancangan Acak Lengkap (RAL) (Steel danTorrie
1991), yang terdiri dari 4 perlakuan dan 5 ulangan. Setiap ulangan terdiri dari 5 ekor ayam pedaging, sehingga jumlah keseluruhan ayam pedaging yang digunakan dalam penelitian ini adalah 100 ekor.

Susunan ransum perlakuan sebagai berikut :

$\mathrm{R} 0=$ Ransum basal dengan 55\% jagung+0\% tepung bonggol pisang sepatu

$\mathrm{R} 1=$ Ransum basal dengan 50\% jagung+ $5 \%$ tepung bonggol pisang sepatu

$\mathrm{R} 2=$ Ransum basal dengan $45 \%$ jagung+ $10 \%$ tepung bonggol pisang sepatu R3 = Ransum basal dengan 40\% jagung+ $15 \%$ tepung bonggl pisang sepatu 
Variabel yang Diukur:

1. Konsumsi ransum, diperoleh dari selisih antara jumlah ransum yang diberikan dengan ransum sisa setiap hari pada setiap unit kandang, dan diakumulasikan pada akhir penelitian.

2. Pertambahan berat badan, merupakan selisih dari bobot akhir (panen) dikurangi dengan bobot badan awal selama penelitian, kemdian dibagi dengan jumlah ayam per unit kandang.

3. Konversi ransum, dihitung berdasarkan perbandingan antara jumlah konsumsi ransum dengan pertambahan bobot badan selama penelitian.

\section{Tatalaksana Penelitian}

Ternak percobaan diletakkan secara acak ke dalam 20 unit kandang, dengan tiap unit ditempatkan 5 ekor ayam broiler umur 1 hari secara acak. Pemberian ransum percobaan dilakukan pada ayam broiler umur 1 minggu. Pakan diberikan pagi dan sore hari.Sebelum pakan diberikan ditimbang terlebih dulu, bila ada pakan sisa, pakan tersebut harus ditimbang untuk mendapatkan data konsumsi pakan. Data bobot badan diperoleh dengan cara menimbang ayam setiap minggu.

\section{Proses Pembuatan Tepung Bonggol Pisang Sepatu}

Proses dalam pembuatan tepung bonggol pisang dapat dilihat pada Gambar 1. berikut ini:

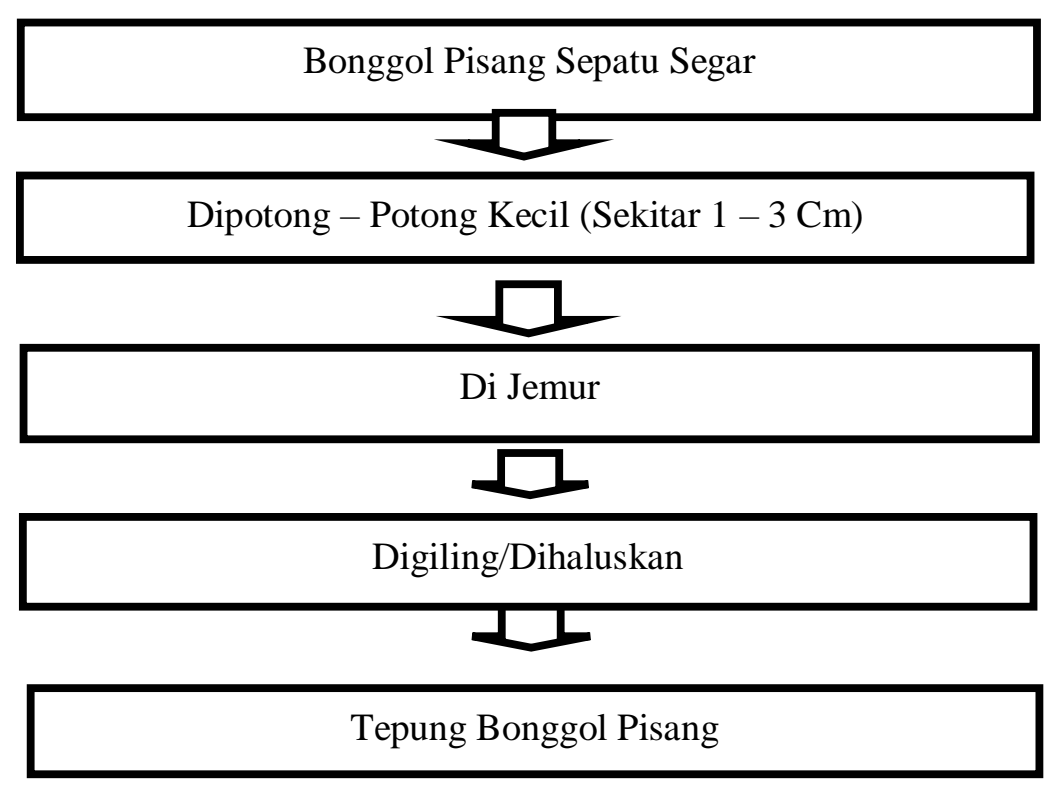

Gambar 1. Proses Pembuatan Tepung Bonggol Pisang Sepatu (Musa paradisiaca L.) 


\section{HASIL DAN PEMBAHASAN}

\section{Pengaruh Perlakuan Terhadap Konsumsi Ransum}

Data hasil perhitungan rataan konsumsi ransum dari masing-masing perlakuan selama penelitian dapat dilihat pada Tabel 3. Terlihat pada Tabel 3 bahwa nilai rataan konsumsi ransum berkisar antara 47,09-50,10 g/ekor/hari. Rataan konsumsi ransum tertinggi terdapat pada perlakuan tanpa penggunaan bonggol pisang sepatu (R0) dan terendah pada perlakuan penggantianjagung dengan $15 \%$ bonggol pisang sepatu (R3). Rataan konsumsi ransum pada penelitian ini lebih rendahdari kisaran seperti yang dinyatakan Wahyu (2004), bahwa konsumsi ransum broiler 0-6 minggu yaitu 77-135 g/ekor/hari. Berdasarkan hasil analisis keragaman menunjukkan bahwa penggunaan tepung bonggol pisang sepatu dalam ransum memberikan pengaruh yang berbeda nyata $(\mathrm{P}<0,05)$ terhadap konsumsi ransum. Hasil uji BNJ menunjukkan bahwa perlakuan R0 nyata Tabel 3. Pengaruh Bonggol Pisang Terhadap Performans Ayam Broiler

\begin{tabular}{lcccc}
\hline \multirow{2}{*}{ Parameter } & \multicolumn{4}{c}{ Perlakuan } \\
\cline { 2 - 5 } & $\mathrm{R} 0$ & $\mathrm{R} 1$ & $\mathrm{R} 2$ & $\mathrm{R} 3$ \\
\hline Konsumsi Ransum & $50,10^{\mathrm{a}}$ & $49,47^{\mathrm{ab}}$ & $48,56^{\mathrm{ab}}$ & $47,09^{\mathrm{b}}$ \\
Pertambahan Berat Badan & $19,85^{\mathrm{a}}$ & $17,80^{\mathrm{ab}}$ & $17,10^{\mathrm{bc}}$ & $14,97^{\mathrm{c}}$ \\
Konversi Ransum & $2.54^{\mathrm{a}}$ & $2.80^{\mathrm{ab}}$ & $2.84^{\mathrm{ab}}$ & $3.15^{\mathrm{b}}$ \\
\hline Keterangan : superskrip berbeda pada baris yang sama menunjukkan perbedaan nyata (P
\end{tabular}

Keterangan : superskrip berbeda pada baris yang sama menunjukkan perbedaan nyata $(\mathrm{P}<0.05)$.

$(\mathrm{P}<0,05)$ lebih tinggi dibanding dengan perlakuan R3 tetapi R0 berbeda tidak nyata $(\mathrm{P}>0,05)$ denganR1 dan $\mathrm{R} 2$. Konsumsi ransum dipengaruhi oleh beberapa faktor, yaitu rasa, bau, dan warna ransum (Uzer et al., 2013). Ransum perlakuan dalam penelitian ini warnanya lebih gelap pada perlakuan R3 dibandingkan dengan ransum kontrol R0. Hal ini diduga mempengaruhi konsumsi ransum. Selain itu, pada penelitian ini, kandungan energi meningkat seiring meningkatnya penggunaan bonggol pisang sepatu dalam ransum, yang diduga juga mengakibatkan konsumsi ransum menurun.

\section{Pengaruh Perlakuan Terhadap Pertambahan Bobot Badan Ayam Broiler}

Data hasil perhitungan rataan pertambahan bobot badan dari masingmasing perlakuan selama penelitian dapat dilihat pada Tabel 3. Rataan pertambahan bobot badan ayam broiler umur 5 minggu dengan level pemberian bonggol pisang sepatu yang berbeda berkisar antara 14,97 - 19,85 g/ekor/hari 
dengan rataan tertinggi pada perlakuan R0 (tanpa bonggol pisang sepatu)dan terendah pada perlakuan R3 (penggantian jagung dengan $15 \%$ bonggol pisang sepatu). Hasil penelitian ini lebih rendah dari hasil penelitian Koni (2013) yang memperoleh hasil pertambahan bobot badan broiler berkisar antara 23,81-33,35 g/ekor/hari.Berdasarkan hasil analisis keragaman, menunjukkan bahwa penggunaan bonggol pisang sepatu dalam ransum memberikan pengaruh berbeda nyata $(\mathrm{P}<0,05)$ terhadap pertambahan bobot badan broiler. Hasil uji BNJ menunjukkan bahwa, R0 berbeda nyata $(\mathrm{P}<0,05)$ dengan $\mathrm{R} 2$ dan $\mathrm{R} 3$, sementara antara R0 dengan R1tidak berbeda nyata sama halnya R1 dengan R2 dan R2 dengan R3. Penggunaan bonggol pisang sepatu nyata menurunkan pertambahan berat badan broiler, terutama pada perlakuan R3 (15\% bonggol pisang sepatu). Semakin tinggi penggunaan bonggol pisang sepatu maka pertambahan berat badan makin menurun. Hal tersebut sesuai dengan penelitian Hasil penelitian Safitri, et al. (2016) memperlihatkan bahwa substitusi ransum komersil dengan $10 \%$ tepung kulit pisang kepok fermentasi $+6 \%$ bungkil kelapa $+1 \%$ feed supplement tidak berpengaruh nyata terhadap berat badan akhir, pertambahan berat badan, konsumsi ransum, dan konversi ransum ayam broiler.Hasil penelitian ini menunjukkan bahwa penggunaan bonggol pisang sepatu yang semakin tinggi pada setiap perlakuan, maka terjadi peningkatan kandungan energi dalam ransum. Kandungan energi yang tinggi dalam ransum, menyebabkan penurunan konsumsi. Broiler akan berhenti makan ketika kebutuhan energi telah terpenuhi. Menurut Maryuni dan Wibowo (2005) bahwa kandungan energi ransum menentukan besarnya konsumsi ransum karena broiler merupakan ternak yang mengkonsumsi ransum untuk memenuhi kebutuhan energi.

\section{Pengaruh Perlakuan Terhadap Konversi Ransum.}

Data konversi ransum dalam penelitian ini disajikan pada tabel 3.Pada Tabel tersebut terlihat bahwa rataan konversi ransum berkisar antara 2,54 - 3,15. Nilai rataan konversi ransum tertinggi diperoleh pada perlakuan R3(pengantian 15\% bonggol pisang), dan terndah pada perlakuan R0 (0\% bonggol pisang).

Nilai konversi ransum dalam penelitian ini lebih tinggi dibanding dengan penelitian yang dilaporkan Djapili et al. (2016), yaitu berkisar antara 2,62 - 3,09 g/ekor/hari. Nilai konversi ransum yang direkomendasikan oleh Kartasudjana dan Suprijatna (2006) untuk broiler umur 6 minggu adalah 2,35 
g/ekor/hari. Berdasarkan hasil analisis keragaman, menunjukkan bahwa penggunaan tepung bonggol pisang sepatu dalam ransum memberikan pengaruh yang berbeda nyata $(\mathrm{P}<0,05)$ terhadap konversi ransum. Hasil uji BNJ menunjukkan bahwa konversi ransum pada perlakuan R3 berbeda nyata $(\mathrm{P}<0,05) \quad$ lebih tinggi dibanding perlakuan R0, tetapi antara R1, R2, dan R3 berbeda tidak nyata $(\mathrm{P}>0,05)$. Suprijatna et al. (2005) yang menyatakan bahwa konversi ransum sangat dipengaruhi oleh konsumsi dan pertambahan berat badan. Angka konversi ransum yang rendah berarti jumlah pakan yang dikonsumsi untuk menghasilkan satu kilogram daging semakin sedikit. Semakin rendahnya angka konversi ransum maka menunjukkan ternak tersebut semakin efisien dalam penggunaan ransum yang diberikan. Hal ini sejalan dengan pendapat Kartasudjana dan Suprijatna (2006) yang menyatakan bahwa konversi ransum sangat dipengaruh oleh konsumsi dan pertambahan berat badan.

\section{KESIMPULAN}

Berdasarkan hasil penelitian ini dapat disimpulkan bahwa penggunaan bonggol pisang sepatu (Musa paradisiasa L.) dalam ransum sampai dengan $10 \%$ masih memberikan performa ayam broiler yang baik.

\section{DAFTAR PUSTAKA}

Djapili, D., F. Wolayan, I. Untu dan H. Liwe. 2016. Pengaruh penggantian sebagai jagung dengan tepung kulit pisang raja (Musa paradisiaca) dalam ransum terhadap Performan broiler. Jurnal Zootek 36(1): 158166

Koni. 2013.Pengaruh pemanfaatan kulit pisang yang difermentasi terhadap karkas broiler. Jurnal Ilmu Ternak. 18 (2):153-157.

Kartasudjana, R., dan E. Suprijatna. 2006. Manajemen Ternak Unggas. Cetakan Pertama. Penebar Swadaya. Jakarta.

Mandey, J. S., Y. H.S. Kowel, M.N. Regar, and J. R. Leke. 2017. Effect of different level of energy and crude fiber from sawdust in diets on carcass quality of broiler. Journal of the Indonesian Tropical Animal Agriculture 42(4):240-246.

Maryuni, S. S.,dan C. H. Wibowo, 2005. Pengaruh kandungan lisin dan energi metabolis dalam ransum yang mengadung umbi kayu fermentasi terhadap konsumsi ransum dan lemak ayam broiler. Journal of IndonesianTropical Animal Agriculture. 30: 26-33.

Priosoeryanto, B.P., N. Putriyanda, A. R. Listyanti, V. Juniantita, I. Wientarsih, B. F. Prasetyo, and R. Tiuria. 2007. The effect of ambon banana stem sap (Musa paradisiacaforma typica) on the acceleration of wound healing process in mice (Mus 
musculus albinus). Journal of Agriculture and Rural Development in the Tropics and Subtropic. Proceeding of The Mini Workshop Southeast Asia Germany Alumni Network (SfAG)May 3rd, 2007, P.35-49.

Puspitasari,D. K., O. Sjofjan, E. Widodo. 2019. Pengaruh penambahan tepung bonggol pisang pada pakan terhadap berat karkas, persentase karkas, dan lemak abdominal ayam pedaging. Jurnal Nutrisi Ternak Tropis 2 (1): 3341.

Safitri, Y., Zulfan dan H. Latif. 2016. Pengaruh penggunaan tepung kulit pisang kepok fermentasi (Musa paradisiaca normalis) terhadap performan ayam broiler. Jurnal Ilmiah Mahasiswa Pertanian Unsyiah. 1(1):781-784

Saragih, B. 2013. Analisis mutu tepung bonggol pisang dari berbagai varietas dan umur panen yang berbeda. Jurnal Teknologi Industri Boga dan Busana 9 (1): 22-29.

Sumarsih, S., C.I. Sutrisno, dan B. Sulistiyanto. 2009. Kajian penambahan tetes sebagai aditif terhadap kualitas organoleptik dan nutrisi silase kulit pisang. Prosiding Semnas Kebangkitan Peternakan, Semarang 20 Mei 2009. pp. 208-211.

Suprijatna, E., U. Atmamarsono dan R. Kartasudjana. 2005. Ilmu Dasar Ternak Unggas. Penebar Swadaya. Jakarta

Steel, R, C., dan J. H. Torrie. 1991. Prinsip dan Prosedur Statistika.
Gramedia Pustaka Utama. Jakarta.

Suyanti., dan A. Supriyadi. 2008. Pisang, Budi Daya, Pengolahan, dan Prospek Pasar. Penebar Swadana. Jakarta.

Taran, S. Y., V. J. Ballo, dan M. Sinlae. 2015. Pengaruh pemberian tepung bonggol pisang dan tepung daun kelor sebagai pengganti jagung terhadap warna, rasa dan keempukan daging ayam broiler. J. Nukleus Peternakan. 2 (1): 67-74.

Ulfa, M. L., dan I. H. Djunaidi. 2019. Substitusi tepung bonggol pisang dan Indigofera sp. sebagai pengganti bekatul dalam ransum untuk meningkatkan performa ayam broiler. Jurnal Nutrisi Ternak Tropis. 2 (2): 65-72.

Uzer, F., N. Iriyanti dan Roesdiyanto. 2013. Penggunaan pakan fungsional dalam ransum terhadap konsumsi pakan dan pertambahan bobot badan ayam broiler. Jurnal Ilmiah Peternakan. 1 (1): 282-288.

Venkatesh, R., V. Krisna, G. K. Krishnamurthy, K. Pradeepa, and S. R. S. Kumar. 2013. Antibacterial Activity of Ethanol Extract of Musa paradisiacal cv. Puttabale and Musa acuminatecv. Grand Naine .Asian Journal of Pharmceutical and Clinical Research 6(2):167170.

Wahyu, J. 2004. Ilmu Nutrisi Unggas. Cetakan ke-5. Gadjah Mada University Press. Yogyakarta. 